\title{
Pedagogický pracovník v integrovaném vzdělávání1 a integrované výchově
}

\author{
Petra Potměšilová, Miloň Potměšil
}

\begin{abstract}
Abstrakt: Děti a žáci se speciálními vzdělávacími potřebami jsou stále více integrováni do běžného výchovně-vzdělávacího procesu. $V$ praxi tak může nastat situace, kdy na dítě a žáka se speciálními vzdělávacími potřebami výchovně působí i pedagogický pracovník, který nemá speciálněpedagogické vzdělání. Cílem příspěvku je nejen stručně charakterizovat podmínky integrovaného vzdělávání a integrované výchovy, ale na základě vyslovených obav ze strany pedagogických pracovníkü² navrhnout možnosti jejich podpory. Obavy pedagogických pracovníků v integrovaném vzdělávání byly analyzovány kvalitativní metodou trsů. ${ }^{3}$ Výsledky analýzy jsou pak dány do kontextu situace sociálního pedagoga. Navržená podpůrná opatření jsou rozdělena na formu možné prípravy a na formu možné následné podpory v praxi a vycházejí z praktických zkušeností z př́pravy studentů sociální pedagogiky na Cyrilometodějské teologické fakultě Univerzity Palackého v Olomouci.
\end{abstract}

Klíčová slova: pedagog, sociální pedagog, integrace, výchovně-vzdělávací proces, dítě a žák se speciálními vzdělávacími potřebami

\section{UVEDENÍ DO PROBLEMATIKY}

Jedinci s postižením se ve společnosti vyskytuji od jejího samotného začátku. Vztah $\mathrm{k}$ těmto lidem se však v průběhu historie výrazně měnil a procházel velkým vývojem. Zpočátku bylo pro společnost typické se jedinců s postižením nejrůznějším způsobem zbavovat, později se začínají objevovat první známky péče o tyto jedince. $V$ současné době se společnost snaží o pozitivní přístup $\mathrm{k}$ jedincům s postižením a o to, aby byli přijímáni jako běžná součást společnosti. Toto přijetí úzce souvisí se změnou ve vnímání normality společnosti. Postupně docházelo $\mathrm{k}$ posunu pojetí normality od toho, že společnost je normální, když je bez postižených, až k tomu, že společnost zůstává normální, i když se v ní objevují lidé s postižením. Tento výrazný posun ve vnímání lidí s postižením intaktní společností se odráží i v jejich pojmenování. Postupně došlo $k$ tomu, že se již nepoužívají názvy a označení, které měly negativní či hodnoticí akcent. V současné době se tedy používá pojem jedinec $s$ postižením a v prípadě dětí a žáků pak dítě či žák se speciálními vzdělávacími potřebami. $V$ anglicky mluvícím prostředí se tak setkáváme s pojmy persons with Disabilities, people with Disability nebo

\footnotetext{
${ }^{1}$ Jsme si vědomi toho, že Ministerstvo školství mládeže a tělovýchovy ČR v souvislosti s integrací dětí a žáků do hlavního vzdělávacího proudu používá termín inkluzivní vzdělávání. (http://www.msmt.cz/socialniprogramy/obsazeni-useku) Pojmy integrace a inkluze jsou v praxi pojímány různě. Průcha (2002) tyto pojmy používá spíše jako synonyma. Potměšil (2010) nebo Kocurová (2002) vnímají mezi těmito pojmy rozdíl. $V$ pojetí těchto dvou autorů je integrace chápána jako proces, který respektuje odlišnosti dvou skupin (žáků s postižením a žáků intaktních) a snaží se o začlenění žáků s postižením do skupiny žáků intaktních. Inkluze je pak v jejich pojetí charakterizována jako práce $s$ žáky, kteří se nečlenění do skupin dle výše uvedeného klíče, ale $\checkmark$ rámci jedné skupiny se $s$ žáky pracuje na základě jejich individuálních schopností. Vzhledem $k$ tomu, že akceptujeme toto rozdělení pojmů, používáme v celém příspěvku termín integrované vzdělávání, který více odráží reálnou situaci v českém vzdělávacím systému.

2 Jedná se o výzkum, který byl autory proveden v letech 2011-2012. Celý výzkum pak byl publikován v rámci monografie Supervize v podmínkách speciálního vzdělávání. (Potměšilová, 2014)

${ }^{3}$ Dtto
} 
adults, children with Special Needs. Na první pohled to může vypadat jako zbytečné „slovíčkaření", ale tento způsob označování lidí s postižením v sobě má velkou hloubku: přiznáváme jedincům s postižením to, že na prvním místě se jedná o lidi, teprve na místě druhém je pak uvedena konkrétní charakteristika dané osoby: člověk malý, člověk s vousy, člověk sportovně založený anebo člověk s postižením. Vhodné pojmenovávání věcí, situací a okruhů lidí ve společnosti je možné považovat za první a důležitý krok ke změně postojů společnosti vůči dané věci, situaci nebo okruhu lidí. Ve vztahu k jedincům s postižením to znamená, že je budeme nazývat lidmi, ale budeme k nim tak i přistupovat.

Sociální pedagog je jedním z pedagogických pracovníků, který se ve své praxi může setkat i s jedinci s postižením. Kraus $(2008$, s. 45) sociální pedagogiku definoval jako disciplínu, která pojednává o tom, jak optimalizovat a usměrňovat životní situace a procesy, a to s akcentem na vnitřní potenciál jedince a jeho individualitu. Aby sociální pedagog mohl plně pracovat s vnitřním potenciálem a individualitou jedince se zdravotním postižením a dále je rozvíjet, měl by mít $\mathrm{k}$ tomu potřebné kompetence.

Dle výše uvedené definice se sociální pedagog může podílet na výchovně-vzdělávacích aktivitách dětí a žáků se zdravotním postižením. Dalším prostorem vzájemného setkání sociálního pedagoga a dětí a žáků se zdravotním postižením jsou i školská zařízení hlavního vzdělávacího proudu. $V$ případě volnočasových zařizení by měl být sociální pedagog schopen pro dítě či žáka se zdravotním postižením vytvořit takové podmínky, respektive upravit prostředí tak, aby se mohli plně, dle svých možností, účastnit jednotlivých aktivit. V rámci školských zařízení pak sociální pedagog často tvoří pomysIný most mezi minoritními jedinci a majoritní společností. $V$ prípadě dítěte či žáka se zdravotním postižením by tak měl být schopen bořit mýty a předsudky ostatních dětí a žáků, respektive rodičů.

Vzhledem k výše uvedeným skutečnostem považujeme za důležité charakterizovat možné obavy ze strany pedagogických pracovníků, kteří nemají speciálněpedagogické vzdělání ve vztahu k této cílové skupině, a na základě těchto obav navrhnout možná preventivní, ale i intervenční opatření.

\section{MOŽNOSTI VÝCHOVNĚ-VZDĚLÁVACÍHO PROCESU DĚTí A ŽÁKŮ SE SPECIÁLNÍMI VZDĚLÁVACÍMI POTŘEBAMI}

Jednou z možností, jak potvrdit či ukázat, že lidé s postižením jsou vnímáni jako běžná součást společnosti, je i to, že mají právo na výchovně-vzdělávací proces v takové formě, která jim bude vyhovovat. Výchovně-vzdělávací proces dětí a žákủ se speciálními vzdělávacími potřebami upravuje v první řadě zákon č. 561/2004 Sb., o předškolním, základním, středním, vyšším odborném a jiném vzdělávání (školský zákon), ve znění pozdějších předpisů, dále pak vyhláška č. 73/2005 Sb. ve znění novely č. 147/2011 Sb., o vzdělávání dětí, žáků a studentů se speciálními vzdělávacími potřebami a dětí, žáků a studentů mimořádně nadaných. Oba dva legislativní dokumenty umožňují dětem a žákům se speciálními vzdělávacími potřebami tři základní formy vzdělávání:

- individuální integrace,

- skupinová integrace,

- Vzdělávání ve speciálních školách.

\subsection{Integrované vzdělávání}

V roce 1994 bylo poprvé deklarováno právo dětí a žáků se speciálními vzdělávacími potřebami na inkluzivní vzdělávání. V tomto roce organizace UNESCO spolu se španělskou vládou uspořádala konferenci na téma Vzdělávání žáků se speciálními vzdělávacími potřebami, kde se vlády 92 zemí usnesly na změně vzdělávacího systému žáků se speciálními vzdělávacími potřebami. Deklarace je dnes známá jako „Prohlášení ze Salamanky“. (The Salamanca Statement, 1994) 
VČeské republice je integrované vzdělávání ve výše uvedených legislativních předpisech charakterizováno jako jedna z forem speciálního vzdělávání. Ve společnosti je však rozšířena představa, že se jedná o běžný typ vzdělávání, tedy vzdělávání dětí a žáků intaktních a těch, kteří mají takový typ a stupeň postižení, které jim nijak nebrání se tohoto typu vzdělávání účastnit. Toto můžeme pak považovat za př́činu odlišného pojetí integrovaného vzdělávání laickou a odbornou veřejností. $O$ odlišném pojetí se zmiňujeme proto, že může být a v praxi často bývá př́činou předsudků, mýtů a nedorozumění v souvislosti s realizací výchovně-vzdělávacího procesu.

Vlastní integrované vzdělávání má dvě základní formy, které jsou vymezeny $v \S 16$ zákona č. 561/2004 Sb. (tzv. školský zákon) ve znění pozdějších novel: individuální integrace a skupinová integrace.

Individuální integrací se rozumí začlenění žáka do běžného vzdělávacího proudu za předem stanovených podmínek. Skupinová integrace je charakterizovaná tím, že se v rámci výchovněvzdělávací instituce zřídí třída či $v$ rámci třídy oddělení nebo studijní skupina pro žáky, kteří mají stejný či podobný typ speciálních vzdělávacích potřeb. Tato třída či oddělení a studijní skupiny pracují dle předem stanoveného plánu.

Vyhláška č. 73/2005 Sb. ve znění novely č. 147/2011 Sb., o vzdělávání dětí, žáků a studentů se speciálními vzdělávacími potřebami a dětí, žáků a studentů mimořádně nadaných, stanovuje přesné podmínky integrace těchto žáků. Mezi tyto podmínky patří právo využívat pro svoje vzdělávání různou škálu vyrovnávacích a podpůrných opatření.

Výše zmíněná vyhláška č. 73/2005 Sb. ve znění novely č. 147/2011 Sb. charakterizuje vyrovnávací opatření jako pedagogické, speciálněpedagogické metody a postupy, které odpovídají vzdělávacím potřebám žáků, poskytování individuální podpory v rámci výuky a prípravy na výuku, využívání poradenských služeb školy a školských poradenských zařizení, individuálního vzdělávacího plánu $a v$ prípadě žáků se sociálním znevýhodněním služeb asistenta pedagoga.

Podpůrnými opatřeními při vzdělávání dětí a žáků se zdravotním postižením pak tato vyhláška definuje: využití speciálních metod, postupů, forem a prostředků vzdělávání, kompenzačních, rehabilitačních a učebních pomůcek, speciálních učebnic a didaktických materiálů, zařazení predmètů speciálněpedagogické péče, poskytování pedagogicko-psychologických služeb, zajištění služeb asistenta pedagoga, snižení počtu žákủ ve třídě nebo studijní skupině nebo jiná úprava organizace vzdělávání zohledňující speciální vzdělávací potřeby žáka.

Cílem těchto opatření je vyrovnat znevýhodnění dětí a žáků tak, aby se mohli účastnit výchovněvzdělávacího procesu v hlavním vzdělávacím proudu, a ne jen pouze ve speciálních školách. Míra a druh vyrovnávacích a podpưrných opatření se stanovuje na základě odborného vyšetření a stanovené diagnózy, typu a stupně postižení či znevýhodnění.

Aby integrace byla funkční a úspěšná, je potřeba vzít v úvahu tři základní faktory, které Michalík (In: Müller a kol., 2004) nazývá základními pilírí: jedinec s postižením, rodina a škola (resp. výchovněvzdělávací zařízení).

\section{Jedinec $s$ postižením}

Vhodnost a úspěšnost integrace závisí i na typu a stupni postižení. Od roku 2005 byla v České republice umožněna forma integrovaného vzdělávání i dětem a žákưm s mentálním postižením. (vyhláška č. 73/2005) V současné době je integrované vzdělávání umožněno všem dětem a žákủm se speciálními vzdělávacími potřebami, kteří prošli speciálněpedagogickým vyšetřením, prípadně pedagogicko-psychologickým vyšetřením a na základě tohoto vyšetření je jim doporučeno.

Integrované vzdělávání však nemusí být vhodné pro každého. $V$ rámci jedné z mnoha přednášek řekl prof. Matějček (ned.), že integrace je to: ... když je dítě s ostatními dětmi, ne vedle nich. Ze zkušeností z praxe můžeme uvést, že integrace žáka s těžkým sluchovým postižením a těžkým mentálním postižením je velmi problematická vzhledem knízké úrovni jazykových, a tedy i komunikačních 
kompetencí. $\mathrm{K}$ možným problémům integrace žáků se sluchovým postižením se blíže vyjadřuje např. Harris (2003). V obou případech, i když z jiného důvodu, často dochází k tomu, že dítě či žák zůstává více vedle kolektivu, než by se stal jeho součástí.

\section{Rodina}

Úspěšná integrace je závislá i na rodině dítěte a žáka s postižením. Od rodičů je vyžadována větší osobní angažovanost a podpora než v př́ípadě, že je umístěno ve speciální škole. (Michalík In: Müller a kol., 2004) Jestliže rodiče adekvátním způsobem podporují své dítě, je pravděpodobné, že mu integrace přinese užitek. Opakem jsou však rodiče, kteří integraci chápou jen jako cíl, nikoliv proces. Jestliže si rodiče myslí, že zařazením jejich dítěte do hlavního vzdělávacího proudu byla integrace dokončena, může dojít $\mathrm{k}$ tomu, že nebudou se školou dostatečným způsobem spolupracovat a své dítě podporovat. Dalším problémem může být situace, kdy rodiče trvají na integraci za každou cenu, i když ze speciálněpedagogického pohledu to není v zájmu dítěte. (např. Kunc, 2000) Tyto dva faktory pak můžeme vnímat z pohledu pedagogického pracovníka v integrovaném vzdělávání za stresující.

\section{Škola (resp. výchovně-vzdělávací zařizení)}

Tento pilíŕ je v souvislosti s tématem předkládaného příspěvku možné považovat za nejdůležitější. Úspěšná integrace je závislá na klimatu celé školy (zařízení), tedy na jejím (jeho) vstřícném nastavení k přijímání žáků se speciálními vzdělávacími potřebami jejich vzdělávání. Michalík (Müller a kol. 2004) uvádí v souvislosti se školou další faktory, které se podílejí na funkční integraci: učitelé, poradenství a diagnostika, asistent pedagoga, př́tomnost kompenzačních pomůcek, vhodně vypracovaný individuální vzdělávací program, architektonické bariéry. Tyto faktory ovlivňují úspěšnost integračního procesu i v ostatních výchovně-vzdělávacích zařízeních.

Vstřícné klima zařízení je sice základ, ale nestačí. Důraz je potřeba dát na dobře vytvořenou diagnózu, na základě které se pak vytvárí návrh formy vzdělávání a míra a typ podpưrných a vyrovnávacích opatření. Pedagogický pracovník má možnost při tvorbě individuálního vzdělávacího plánu spolupracovat se speciálněpedagogickým centrem či pedagogicko-psychologickou poradnou. Pokud dobře nefunguje jeden $z$ těchto článků, může dojít $k$ tomu, že integrační proces nebude plnit svoji funkci.

\subsubsection{Integrované vzdělávání v České republice $v$ čislech}

Vančurová (2011) uvádí, že teprve ve školním roce 2010/2011 poprvé poklesl počet žáků ve speciálních třídách a zvýšil se počet žáků individuálně integrovaných. Tento trend se pak podařilo udržet i další školní rok. Z uvedených dat je tedy patrné, že je v současné době v naší společnosti patrná snaha o podporu individuální integrace dětí a žáků se speciálními vzdělávacími potřebami do hlavního vzdělávacího proudu.

Z dalších statistik Českého statistického úřadu vyplývá, že v letech 1990 až 2004 nejvyšší procento žáků speciálních škol tvořili žáci s mentální retardací. Ve školním roce 1990/1991 to bylo 78 \% a ve školním roce 2004/2005 to bylo necelých $61 \%$. Ve sledovaném období počet žáků s mentální retardací výrazně klesal, přesto však stále tvoří největší část žáků všech speciálních škol. Další, z pohledu statistiky zajímavou kategorí jsou žáci s kombinovaným postižením. V této kategorii Český statistický úřad zaznamenal opačný trend. Ve školním roce 1990/1991 tvořili 4,5% z celkového počtu žáků speciálních škol, ve školním roce 2004/2005 pak 21,5 \%.

Z výše uvedených údajů je patrné, že v letech 1990-2004 došlo k poklesu počtu žáků s mentální retardací ve speciálních školách o $17 \%$. Tento pokles může být dán změnou legislativy. Od 5. 1. 2004 nabyla účinnosti novela vyhlášky č. 291/1991 Sb., o základní škole. Novela vyhlášky se týkala rozšírení paragrafu 3 o odstavec, v němž je nově stanovena možnost integrace i pro žáky s mentálním postižením. Tato změna byla podložena tzv. pokusným ověřováním, $v$ rámci kterého byli do vybraných škol integrováni žáci s mentálním postižením. 
Zde spatřujeme možný základní problém a střet dvojího pojetí integrovaného vzdělávání. Pedagogičtí pracovníci jsou připravováni na práci s intaktními žáky a žáky s lehkým typem postižení, kteří nepotřebují zvláštní podpůrné a vyrovnávací opatření. Změnou pojetí integrovaného vzdělávání a rozšířením cílové skupiny se mění i nároky na pedagogické pracovníky. Pedagogičtí pracovníci tuto změnu vnímají především ve dvou oblastech: v prípravě na povolání a v náplni jejich práce.

Zvyšování počtu dětí a žáků, kteří jsou individuálně integrovaní, vede i ke zvyšování počtu pedagogických pracovníků hlavního vzdělávacího proudu, kteří potřebují odbornou př́pravu pro práci $s$ těmito dětmi a žáky. Cílovou skupinou pro přípravu na práci s dětmi a žáky se speciálními vzdělávacími potřebami se tak kromě budoucích speciálních pedagogů stávají i pedagogičtí pracovníci hlavního vzdělávacího proudu.

\section{3 ŠETŘENÍ}

Výsledky, které zde uvádíme, jsou dílčími výsledky většího výzkumu4 ${ }^{4}$ který se zabýval vztahem pedagogických pracovníků pracujících s klienty s postižením $\mathrm{k}$ potřebě podpůrných opatření pro jejich práci. Výzkum měl dvě části. Do první části výzkumu bylo zahrnuto 292 respondentů. Všichni respondenti byli pouze pedagogičtí pracovníci v integrovaném vzdělávání v předškolních zařizeních a základních školách. Do druhé části výzkumu pak byli zahrnuti i pedagogičtí pracovníci pracující ve speciálních školách a zařízeních. Zde se budeme zabývat pouze první částí výzkumu. Tato část výzkumu byla zpracována v kvalitativním designu.

\section{Cíl výzkumu:}

Nalézt a charakterizovat faktory, které vnímají pedagogičtí pracovníci v souvislosti s integrovaným výchovně-vzdělávacím procesem jako rizikové a které tak mohou následně ovlivnit jejich postoje a prístupy $\mathrm{k}$ tomuto procesu.

\section{Výzkumná otázka:}

VA 1. Vnímají pedagogičtí pracovníci v souvislosti s integrovaným výchovně-vzdělávacím procesem nějaké obavy; pokud ano, tak jaké?

\section{Výzkumný vzorek:}

Jak už bylo výše uvedeno, výzkumu se zúčastnilo 292 respondentů. Respondent, který byl zahrnut do výzkumu, musel splňovat dvě základní podmínky:

- absence speciálněpedagogického vzdělání,

- pedagogická práce s dítětem či žákem se speciálními vzdělávacími potřebami.

Z pedagogických pracovníků, kteří splňovali výše uvedená kritéria, byla náhodným výběrem sestavena skupina respondentů. Převážně se jednalo o respondenty $z$ řad studentů kombinované formy sociální pedagogiky a z řad pedagogů, kteří se přihlásili na seminář v rámci projektu „Standardy speciální edukace".

Při výběru vzorku respondentů jsme vycházeli ze současného trendu integrovaného vzdělávání, tedy ze situace, kdy se zvyšuje počet pedagogických pracovníků, kteří se při své práci setkávají s klienty s postižením. Jedná se o pedagogické pracovníky, kteří nemají speciálněpedagogické vzdělání a primárně si práci s klienty s postižením nevybrali. Uvedené dva důvody mǔžeme považovat za faktory zvýšené zátěže $v$ práci pedagogických pracovníkủ, které se u nich mohou stát př́činou výskytu

\footnotetext{
${ }^{4}$ Jak již bylo uvedeno v úvodu, jedná se o výzkum, který byl prováděn v letech 2011-2012. Celý výzkum je publikován v monografii Supervize v podmínkách speciálního vzdělávání. (Potměšilová, 2014)
} 
nežádoucích jevů. Mezi základní nežádoucí jevy, které souvisejí s výkonem pedagogické profese, patří: syndrom vyhoření, syndrom pomocníka a zneužití moci. (Baštecká a kol., 2003; Vágnerová, 2000; Géringová, 2011; Hawkins, 2004)

\section{Výzkumné metody:}

Za výzkumnou metodu byla zvolena analýza materiálů, a to konkrétně pomocí metody trsů. ${ }^{5}$ Respondenti byli požádáni, aby zpracovali písemnou práci na téma „Možnosti a meze integračního vzdělávání v podmínkách vybraného zařízení" na základě vlastních zkušeností.

\section{Výsledky:}

Od spolupracujících respondentů ${ }^{6}$ bylo získáno přes 2500 stran textu. Vzhledem k zvolené metodě analýzy dat, metodě trsů, byl text analyzován a následně detekovány základní položky, v nichž se objevily pojmy: strach a obavy. Na základě další analýzy textu byly přidány pojmy: nedůvěra, problém, rozložení, změna, nesouhlas, starosti, zátěž a hodnocení. Celkem bylo vybráno 19 položek, které se vyskytovaly v různé četnosti ${ }^{7}$. Těchto 19 položek pak bylo rozděleno do 4 obecných položek - trsů:

1. nepedagogické činnosti nad rámec běžného vzdělávání

a. pedagog má zbytečné starosti navíc,

b. finanční náročnost pomůcek,

c. podpora žáka v každodenních situacích (toaleta, jídlo),

d. administrativní a pracovní zátěž,

e. fyzicky náročné zvedání klientů,

2. pedagogické činnosti nad rámec běžného vzdělávání

a. narušení výchovného procesu ostatních žáků,

b. určitý typ postižení je pro školu spiše zátěží - vliv na práci učitele,

c. klima tř́dy může být narušeno,

3. zvýšené nároky na prípravu a realizaci pedagogické práce
a. náročnější príprava učitelů na vyučování,
b. potřeba odpočinkových pauz - úprava organizace výuky,
c. zátěž i pro ostatní spolužáky - vliv na př́pravu výuky,
d. hodnocení žáků,
e. uzpůsobení rozvrhu a chodu školy,
f. náročnost integrace dítěte s ADHD - vliv na psychiku učitele,

4. kompetence a nástroje za hranicí běžného vzdělávání
a. nedostatek informací, odkud brát podporu (SPC, PPP, ...),
b. vzdělání ve speciální pedagogice,
c. překračování kompetencí a rolí (krizová intervence pro rodiče a žáky),
d. práce navíc - neodpovídající platové ohodnocení,
e. tlak ze strany rodičů.

\footnotetext{
${ }^{5}$ Metodu trsů jsme volili s odvoláním na teorii kvalitativní analýzy ve výzkumu a také vzhledem k tendenci k možné konceptualizaci výroků a také k překrývání mezi sledovanými jednotkami tak, jak to uvádí např. Miovský (2006).

${ }^{6}$ Vzhledem $\mathrm{k}$ tomu, že zde dále nepracujeme $\mathrm{s}$ daty, jako je pohlaví, věk, délka praxe, data v tomto příspěvku neuvádíme.

7 Četnost položek vanalyzovaném textu byla sice různá, ale nikoliv významně. Z tohoto důvodu ji zde neuvádíme.
} 


\section{Interpretace: ${ }^{8}$}

Ve výše uvedených trsech je reflektován pocit pedagogických pracovníků v integrovaném vzdělávání, který indikoval, že přítomnost žáka se speciálními vzdělávacími potřebami je potencionální zátěží nejen pro ně samotné, ale i pro ostatní žáky. Pedagogičtí pracovníci si dále uvědomují možný nárůst pracovních povinností a změnu kompetencí v kontrastu s nedostatečnou odbornou připraveností pro práci s těmito žáky.

\section{Nepedagogické činnosti nad rámec běžného vzdělávání}

Pro analýzu textu bylo důležité, že se oblast nepedagogických činností nad rámec běžného vzdělávání vyskytovala poměrně často. Může to souviset s tím, že pedagogičtí pracovníci nemají zatím dostatek informací o charakteristice jednotlivých postižení, a také $s$ tím, že v médiích jsou často prezentovány problémy klientů s těžkým stupněm postižením. $V$ kap. 2 jsme uvedli, že funkční integrace je závislá na třech základních piliřích. Jedním z těchto piliřu je sám žák a typ a stupeň jeho postižení, což znamená, že pro integrované vzdělávání by měli být doporučováni ti žáci, kteří jsou schopni zvládat vzdělávání $v$ běžném typu škol. $V$ prípadě integrace dětí a žáků s tě̌̌ším stupněm postižení je součástí rozhodnutí i doporučení podpůrných a vyrovnávacích opatření, ale především i doporučení nebo požadavek na dalšího pedagogického pracovníka - asistenta pedagoga. Asistent pedagoga podle $\S 7$ vyhlášky č. 73/2005 Sb. ve znění novely č. 147/2011 má v náplni své práce:

a. pomoc pedagogickým pracovníkům školy při výchovné a vzdělávací činnosti, pomoc při komunikaci se žáky a zákonnými zástupci žáků a komunitou, ze které žák pochází,

b. podpora žákům při přizpůsobení se školnímu prostředí,

c. pomoc žákům při výuce a při prípravě na výuku,

d. nezbytná pomoc žákům s těžkým zdravotním postižením při sebeobsluze a pohybu během vyučování a při akcích pořádaných školou mimo místo, kde škola v souladu se zápisem do školského rejstříku uskutečňuje vzdělávání.

$Z$ bodu $d$. tedy vyplývá, že činnost, ze které někteří pedagogičtí pracovníci integrovaného vzdělávání mají strach, je v kompetenci asistenta pedagoga. $V$ praxi však může nastat situace, kdy tuto činnost bude vykonávat pedagog (např. při volnočasových aktivitách). Proto by měla být výše zmíněná problematika zařazena do př́pravy pedagogických pracovníků na integrované vzdělávání.

\section{Pedagogická činnost nad rámec běžného vzdělávání}

Za důležité $v$ tomto trsu Ize považovat to, že se zde nejvíce objevovala obava o vliv prítomnosti žáka s postižením na ostatní spolužáky. $V$ textu se často objevovala situace, kdy si pedagogický pracovník nebyl jistý tím, co má dělat v prípadě přítomnosti žáka S ADHD: „Mám strach, že když P. dostane možnost se proběhnout, že to budou chtít i ostatní (R 23); „Když má J. den, tak mi rozloží celou tř́́du“ (R 125). Z tohoto trsu vyplývá, že při přípravě a následné podpoře pedagogických pracovníků v integrovaném vzdělávání je potřeba se zaměřit na způsob organizace vlastní výuky za přítomnosti žáka se speciálními vzdělávacími potřebami.

\section{Zvýšené nároky na přípravu a realizaci výuky}

Tento okruh úzce souvisí s předcházejícím a do jisté míry by mu měl spiše předcházet. Logicky můžeme usuzovat na to, že pokud je dobře připraven výchovně-vzdělávací proces, měl by také dobře fungovat. Z hlediska našeho výzkumu chápeme tyto trsy odděleně, protože poukazují na možnou šíri dopadu prítomnosti dítěte a žáka se speciálními vzdělávacími potřebami vhlavním výchovněvzdělávacím proudu.

\footnotetext{
${ }^{8} \mathrm{~V}$ textu jsou uvedeny př́mé citace z textu, který zpracovávali respondenti. Pro přehledné zpracování výsledků bylo každému z respondentů přiděleno číslo (R1-R292).
} 
Pedagogičtí pracovníci se často zmiňovali o náročné přípravě na vyučování: „Vlastně hodinu připravuji dvakrát, jednou pro M. a podruhé pro ostatní (R 5); „Musela jsem do prípravy na vyučování zařadit i aktivity, které bych normálně nepoužívala (odpočinek)“ (R 209). Dalším častým problémem je pak hodnocení a známkování: „Občas ji hodnotím mírněji než ostatní, je mi jí líto a navíc, když se tak snaží..." (R 55).

Zvýšené nároky na přípravu a realizaci se pak netýkají jen výuky, stejně zvýšené nároky na přípravu mohou pedagogičtí pracovníci vnímat a často i vnímají při prípravě různých volnočasových aktivit.

\section{Kompetence a nástroje za hranicí běžného vzdělávání}

Za klíčové v této oblasti Ize považovat to, že sami pedagogičtí pracovníci si uvědomují potřebu speciálněpedagogické kvalifikace a potřebu podpory či metodického vedení ze strany speciálněpedagogického centra. Oba tyto jevy budou důležitými faktory v prípravě podpůrných opatření pro pedagogické pracovníky.

Za zajímavý faktor Ize považovat strach z překračování rolí, konkrétně z možnosti poskytovat krizovou intervenci rodičům žáka se speciálními vzdělávacími potřebami. $V$ praxi speciálního pedagoga se může stát, že si rodiče $\mathrm{k}$ němu vytvoří silnější vztah, než jak tomu bývá v hlavním vzdělávacím proudu. Ve většině případů se tento silnější vztah projevuje ve vyšší frekvenci diskuse rodičů a pedagoga a jejich větší spolupráci. Ani v kompetencích speciálního pedagoga však není poskytovat rodičům krizovou intervenci. Zmíněný strach z možnosti poskytovat krizovou intervenci rodičùm žáka se speciálními vzdělávacími potřebami vnímáme spíše jako důsledek předsudků vůči jedincům s postižením a jejich okolí. Předsudky často vznikají z neznalosti ${ }^{9}$ dané problematiky, nedostatku zkušeností a také ze strachu. Ve společnosti je obecně rozšířená představa o tom, že být postižený, také znamená být nešt́astný. Opět i tento významový trs bude důležitým faktorem při přípravě podpůrných opatření pro pedagogické pracovníky.

\subsection{Validizace výzkumné otázky}

Na základě podrobné analýzy dat můžeme tedy na výzkumnou otázku, která je uvedena na začátku kap. 3, odpovědět: Pedagogičtí pracovníci vnímají v souvislosti s integrací dětí a žáků se speciálními vzdělávacími potřebami čtyři základní okruhy rizik:

1. výskyt nepedagogických činností nad rámec běžného vzdělávání,

2. výskyt pedagogických činností nad rámec běžného vzdělávání,

3. zvýšený nárok na př́ípravu a realizaci pedagogické práce,

4. změna rozsahu kompetencí a nástrojů.

Dále si uvědomují, že realizace integrovaného vzdělávání může mít vliv nejen na ně samotné, ale i na ostatní žáky, respektive na celou školu.

\subsection{Závěry šetření}

Vyjádřené obavy je možné považovat za pozitivní signál toho, že oslovení pedagogičtí pracovníci si uvědomují závažnost dané problematiky a jsou schopni realistického náhledu. Uvedené obavy Ize považovat za významné informace o tom, co by pedagogičtí pracovníci integrovaného vzdělávání potřebovali k tomu, aby integrace žáka se speciálními potřebami byla z pohledu školy úspěšná. Výše zmíněné obavy se tedy stanou potřebnými východisky pro vytváření systému podpory.

\footnotetext{
9 Ve společnosti je obecně rozšířená představa o tom, že být postižený také znamená být neštastný.
} 


\section{MOŽNOSTI PODPORY}

Na základě provedeného šetrení je možné podporu pedagogických pracovníků rozdělit do dvou hlavních oblastí: oblast př́pravy a oblast podpory při realizaci integrovaného vzdělávání.

\subsection{Oblast prípravy}

Příprava všech pedagogických pracovníků by měla zahrnovat základní seznámení se speciálněpedagogickou problematikou. Cílem prípravy by nemělo být vytváření nebo výroba dalších speciálních pedagogů, ale připravení poučeného pedagogického pracovníka, který pokud se setká sklientem s postižením, bude schopen s ním adekvátním způsobem komunikovat a voblasti výchovně-vzdělávacího procesu pracovat.

V roce 2012 byl řešen v rámci Fondu rozvoje vysokých škol (dále jen FRVŠ) projekt č. 358/2012, který byl zaměřen na inovaci studijního předmětu „Integrace žáků se speciálními vzdělávacími potřebami“. Cílem inovace bylo vytvořit nové pojetí předmětu tak, aby sociální pedagogové a další studenti získali nejen znalosti, ale především dovednosti pro efektivní komunikaci s klienty s postižením, se kterými se mohou v rámci integrace setkat. Byl vytvořen, po pilotním ověření upraven a dále i v současnosti využíván jednosemestrální seminář, který je nyní rozdělen do několika tematických bloků. $V$ úvodních blocích se studenti bliže seznamují se základní speciálněpedagogickou terminologií, historickými souvislostmi, současným stavem a legislativním zázemím. Tyto bloky vedou k práci s neznalostí a předsudky. Na úvodní bloky navazuje seznámení s jednotlivými skupinami postižení: charakteristika postižení, typy, možnosti komunikace a práce s kompenzačními pomůckami. Závěr semináře je pak zaměřen na zpracovávání individuálního vzdělávacího plánu. Absolventi semináře by měli získat základní kompetence pro práci s klientem s postižením v rámci integrovaného vzdělávání, dále by pak měli mít povědomí o dalších možnostech podpory. Absolventi by tak měli být schopni:

- poznat, o jaký typ speciálně vzdělávacích potřeb se jedná,

- adekvátní komunikace s dítětem,

- úpravy podmínek na základě speciálních vzdělávacích potřeb dítěte.

Na konci daného semestru je pak uspořádána studentská konference. Studenti ve skupinách zpracovávají individuální vzdělávací plán pro vybrané dítě a vybranou volnočasovou aktivitu nebo připravují osvětovou akci na téma vybraného typu postižení.

V současné době se objevují různé projekty, ${ }^{10}$ které se zabývají vytvářením metodických príruček pro práci s žáky se speciálními vzdělávacími potřebami nebo přípravou kurzů pro pedagogické pracovníky integrovaného vzdělávání.

\subsection{Oblast podpory při realizaci integrovaného vzdělávání}

Oblast podpory pedagogických pracovníků vintegrovaném vzdělávání je považována za velmi důležitou. (např. Hess a kol., 2008; Truskovska, 2010) Spilková a kol. (2010) zdůrazňuje fakt, že právě učitel je jedním z kličcových fenoménů, který ovlivňuje celkovou kvalitu školy. V současné době v pedagogické praxi existuje trend, který zdůrazňuje potřebu dalšího vzdělávání pedagogických pracovníků. Tento trend vychází z názoru, že pouze kvalitně připravený pedagogických pracovník může vykonávat svoji práci kvalitně. $V$ dokumentu Národní program rozvoje vzdělávání v České republice (tzv. Bílá kniha) z roku 2001 jsou kvalitní učitelé považování za hlavní aktéry, kteří se podílejí na změnách ve škole. Na Bílou knihu navázal v letech 2000 až 2001 projekt „Podpora práce učitelü“, v rámci kterého byly formulovány profesní standardy v podobě klíčových kompetencí

\footnotetext{
10 Oba typy zmíněných projektů byly realizovány v rámci Ústavu speciálněpedagogických studií na Pedagogické fakultě Univerzity Palackého (hl. řešitelé: M. Potměšil, J. Michalík).
} 
učitelů. (Spilková a kol, 2010) Nároky na učitelskou profesi tak mohly být specifikovány na základě konkrétních vzdělávacích cílů a funkcí školy.

V odborné literatuře (Hess, 2008; Horská, 2009; Spilková, 2010; Píšová, 2011) se v souvislosti s podporou pracovníků v jejich profesi setkáváme se třemi pojmy: koučování, mentoring, supervize. O potřebě podpory různých pracovníků se stále více diskutuje na různých úrovních. Syndrom vyhoření se $v$ určitých profesích objevuje častěji a začíná se objevovat i v dalších profesích, kde dřive nebyl tak častý (již ne jen v pomáhajících profesích, ale i v dalších profesích ${ }^{11}$, v nichž pracovníci přicházejí do pravidelného styku slidmi). V některých profesích (klinický psycholog) je zákonem vymezená podpora (supervize), v jiných profesích tomu tak zatím není. $V$ pedagogické profesi, jak již bylo výše uvedeno, podpora v této formě nemá legislativní oporu.

\subsubsection{Koučování}

Horská (2009, s. 13) definuje koučování v pedagogické praxi jako nedirektivní způsob řizení pedagogických pracovníků, který by měl být opakem přikazování a kontroly. Jedná se o dlouhodobou a specifickou činnost, jejímž cílem je podpora pedagogického pracovníka v profesním a př́padně i osobním růstu. Koučování je postaveno na vztahu kouče a koučovaného. Kouč podporuje koučovaného $v$ převzetí zodpovědnosti v plánování a dosahování vytyčených cílů. Za klíčový prvek v procesu koučování Horská $(2009$, s. 13) považuje facilitaci, tedy jakési usnadnění procesu myšlení koučovaného.

\subsubsection{Mentoring}

Mentoring je starý jako sama civilizace. Jedná se o prirozený vztahový proces, při němž jedna generace předává druhé své zkušenosti a hodnoty. (Stanley a Clinton, 2011, s. 10) Mentor tedy těží ze svých zkušeností, které získal časem při výkonu své profese a může tyto zkušenosti předávat mladším kolegům. Stanley a Clinton (2011) v souvislosti s procesem mentorování zdůrazňují vhodný čas pro mentoring a vhodný způsob mentorování. Pokud jsou naplněny tyto dvě základní podmínky, může dojít k efektivnímu přenosu potřebných zkušeností a hodnot. Pokud však není zvolen vhodný čas nebo vhodný způsob mentorování, cenný proces předávání se stává spíše poučováním a mentorovaný se v tomto vztahu cítí spíše hlídaný či káraný.

Píšová a kol. (2011, s. 46) mentoring v pedagogické profesi vnímá především z pozice podpory pro pedagogické pracovníky a definuje jej jako intencionální, dlouhodobý, situovaný proces podpory poskytovaný učiteli na pracovišti zkušenějším kolegou s cílem facilitovat procesy jeho profesního rozvoje. $Z$ takto vymezeného pojmu mentoring vyplývá, že proces může probíhat a zpravidla i probíhá na formální a neformální úrovni. Formální úroveň, tedy úroveň vymezená legislativním opatřením, v současné době v České republice neexistuje. V některých školách se však jakási formální struktura mentorů vyskytuje. Mnohem častější je však ta neformální ${ }^{12}$, tedy forma jakési kolegiální spolupráce, která však v současné době stále více naráží na trend soutěžení a osobních úspěchů.

\subsubsection{Supervize}

Jednou z možností, jak podporovat pedagogické pracovníky $v$ jejich práci a podporovat je $v$ jejich vývoji, by dále mohla být supervize. O potřebnosti supervize pro pedagogické pracovníky se ve svém článku mimo jiných zmiňuje Truskovska. (2010)

\footnotetext{
${ }^{11}$ Autorka během studia Psychologie na FF UP absolvovala praxi na Psychiatrickém oddělení FNO. Tři čtvrtiny klientů skupiny lidí, kteří trpěli syndromem vyhoření, který se projevil vážnými depresivními stavy, byli prodavači a prodavačky z různých obchodů.

${ }^{12} \mathrm{Na}$ jednom ze sledovaných pracovišt’ takto fungovala starší dáma - učitelka, která vytvořila před 20 lety strukturu předškolního vzdělávání pro danou školu. Kdykoliv přišla na návštěvu, vždy se ráda bavila na téma výchovně-vzdělávacího procesu. Vhodnými otázkami uměla učitele navést na problém a nabídnout řešení. Setkání s ní by se dalo nazvat opravdovým neformálním mentoringem.
} 
Supervize je běžná intervenční technika, kterou pro svoji práci využívají kliničtí psychologové a psychoterapeuti. Současná legislativa však nevymezuje supervizi pro pedagogické pracovníky ve školách ani ve školách pro žáky se speciálními vzdělávacími potřebami. Výjimku pak tvoří Metodický pokyn k poskytování supervize ve školských zařízeních pro výkon ústavní výchovy nebo ochranné výchovy a ve školských zařízeních preventivně výchovné péče, $v$ němž je definován pojem supervize, charakterizována supervize $v$ těchto školských zařízeních a vymezen supervizor a jeho vzdělání.

Podle Hawkinse (2004, s. 59) Hess definuje supervizi jako čistou mezilidskou interakci, jejímž obecným cílem je, aby se jedna osoba, supervizor, setkávala s druhou osobou, supervidovaným, ve snaze zlepšit schopnost supervidovaného účinně pomáhat lidem.

Hawkins (2004, s. 60) uvádí několik základních funkcí supervize, které supervidovanému mohou pomoci v práci: lépe rozumět klientovi, více si uvědomovat své reakce a odezvy na klienta, chápat dynamiku toho, jak probíhají interakce s klientem, podívat se na to, jak intervenují a jaké jsou dopady jejich intervence, zkoumat další způsoby práce s touto a podobnými situacemi klientů.

Falender a Shafranske $(2004$, s. 3) definují supervizi jako odbornou činnost, která může mít formu vzdělávání nebo odborné přípravy. Cílem supervize je pak předávání praktických zkušeností v oblasti fungování mezilidských vztahů.

Podle Rue a Byarse (1990) by supervize měla být první úrovní managementu každé organizace. Na první pohled se může zdát, že takto definovaná supervize by spíše spadala do oblasti pracovní psychologie. Ve skutečnosti tuto definici supervize můžeme považovat za důležitou myšlenku. Pokud by se supervize stala funkční součástí práce pedagogických pracovníků, může mít tato skutečnost pozitivní vliv na fungování celého zařízení.

$\vee$ praxi existuje několik druhů supervize. Druhy supervize, které jsou zde blíže charakterizovány, patří $k$ těm, které se dle našeho průzkumu jeví pro školství jako nejpotřebnější:

prípadová supervize

Případová supervize se zaměřuje na práci supervidovaného s danou klientelou či s daným klientem. Cílem této formy je náhled a sebereflexe na vlastní práci a hledání možných jiných způsobů, které budou funkční.

týmová supervize

Týmová supervize je zaměřena na způsob fungování týmu v dané organizaci: jak probíhá diskuse, jakým způsobem jsou řešeny problémy, jak fungují vztahy. Cílem této formy supervize je vést tým k maximálním výkonům a $\mathrm{k}$ vytváření zdravých vztahů.

rídicí supervize

Řídicí supervize se zaměřuje na způsob vedení organizace a na kompetence rídicích pracovníků. Cílem je vytvořit zdravé a funkční vztahy vedení k pracovníkům organizace.

\section{ZÁVĚR}

Pedagogičtí pracovníci vintegrovaném vzdělávání vnímají př́tomnost žáka se speciálními vzdělávacími potřebami jako rizikovou situaci z pohledu celého výchovně-vzdělávacího procesu. Přesto však se pedagogičtí pracovníci této formě výchovně-vzdělávacího procesu nebrání a spatřují v ní i pozitiva. (Potměšil, 2010) Rizika vnímají především ve své odborné nepřipravenosti na práci $s$ těmito žáky a také $v$ nedostatečné podpoře při vlastní realizaci této formy práce.

Cílem navržených opatření není transformovat sociálního pedagoga do formátu speciálního pedagoga, ale rozšírit jeho kvalifikaci a připravenost pro praxi, a to vzhledem $k$ integračním či inkluzivním trendům společnosti. Sociální pedagog by na základě svého profilu měl být připraven i pro práci s dětmi a žáky se zdravotním postižením právě proto, že je často tím prvním, kdo může měnit pohled druhých na tuto problematiku. Kromě odborné připravenosti by měl mít možnost 
o svých výchovně-vzdělávacích postupech diskutovat a měl by mít možnost získat zpětnou vazbu ke své pedagogické činnosti.

Dříve fungoval ve školských zařízeních tzv. uvádějící pedagog, který během prvního roku dohližel na nově nastoupeného kolegu a pomáhal mu. Mentor by měl $v$ rámci zařízení plnit tuto funkci. $V$ prípadě integrovaného vzdělávání by to mohl být kolega, který má již zkušenost s výchovně-vzdělávací prací žáků a dětí se speciálními vzdělávacími potřebami. Z pohledu speciálního pedagoga se však domníváme, že samotný mentoring nemusí v prípadě integrovaného vzdělávání stačit. $Z$ uvedených obav pedagogických pracovníků integrovaného vzdělávání vyplývá potřeba hlubší a pravidelné podpory těchto pracovníků. Takovouto možnost může nabídnout supervize, $v$ prípadě integrovaného vzdělávání a výchovy pak především případová supervize. $V$ rámci volnočasových zařízení pak výše uvedené skutečnosti mohou mít tu samou platnost. Zkušený kolega je schopen poradit začínajícímu sociálnímu pedagogovi, jak uzpůsobit podmínky pro aktivity dětí a žáků se zdravotním postižením; supervize pak může pomoci $v$ práci nejen $s$ predsudky, ale může pomoci i nasměrovat $k$ funkčnímu výchovně-vzdělávacímu procesu těchto dětí a žáků.

Speciální pedagogika $v$ aktualizovaném paradigmatu je zaměřena na klienta $v$ komplexním, psychosociálním pohledu. Z hlediska aktualizovaných potřeb cílové skupiny je pevně navázána na pedagogiku sociální. Je tedy žrejmé, že speciálněpedagogická problematika a problematika sociálněpedagogická budou oborově pracovat na specifikaci a konkretizaci vzájemného průniku. Sociálněpedagogický kontext je $\mathrm{v}$ současném pojetí práce $\mathrm{s}$ osobami se speciálními potřebami velmi významný, protože je jedním z piliřů, které tvoří most ze světa segregace do prostředí inkluzivního pojetí odlišností, a to jak zdravotních, tak sociálních.

Výsledky uvedeného průzkumu ukazují na důležitou problematiku integrovaného výchovněvzdělávacího procesu. Integrované vzdělávání, ale i integrovaná výchova jsou důležitou součástí výchovně-vzdělávacího systému a z tohoto důvodu je potřeba pro ně vytvořit odpovídající podmínky. Jednou ze zásadních podmínek by měl být systém podpory pro pedagogické pracovníky. Výše jsme uvedli některé možnosti, které úspěšně fungují. Za důležité Ize s odkazem na uvedené závěry tvrdit, že je možnost tyto formy převést i do oblasti pedagogické práce. Konkrétní možnosti využití a popis těchto činností bude předmětem našeho dalšího výzkumu.

\section{LITERATURA}

Baštecká, B. \& kol. (2003) Klinická psychologie v praxi. Praha: Portál.

Falender, C. A. \& Shafranske, E. P. (2004) Clinical Supervision: A Competency-Based Approach. Washington: American Psychological Association.

Géringová, J. (2011) Pomáhajíci profese. Tvořivé zacházení s odvrácenou stranou. Praha: Triton.

Harris, M. (2003) The Importance of Audition in Early Communicaion. Nottingham: The Ear Fundation. Hawkins, P. \& Shonet, R. (2004) Supervize v pomáhajících profesích. Praha: Portál.

Hess, A. K. \& Hess, K.D. \& Hess, T. H. (2008) Psychoterapy Supervision: Theory, Research, and Practice. New Jersey: J. Wiley and Sons.

Horská, V. (2009) Koučování ve školní praxi. Praha: Grada.

Kocurová, M. \& kol. (2002) Speciální pedagogika pro pomáhající profese. Plzeň: ZČU.

Kunc, N. (2000). Integration: Being Realistic Isn't Realistic, Electronic Journal for Inclusive Education, 1 (3), p. 1-9.

Metodický pokyn kposkytování supervize. [online] cit. 27. 4. 2012 dostupné z: http://www.msmt.cz/socialni-programy/metodicky-pokyn-k-poskytovanisupervize?highlightWords=supervize 
Potměšilová \& Potměšil / Pedagogický pracovník v integrovaném vzdělávání ... $\mid \begin{gathered}10 \\ 0\end{gathered}$

Miovský, M. (2006) Kvalitativní prístup a metody v psychologickém výzkumu. Praha: Grada.

Müller, O. \& kol. (2004) Dítě se speciálními vzdělávacími potřebami v běžné škole. Olomouc: UP.

Píšová, M. \& Duschinská, K. \& kol. (2011) Mentoring v učitelství. Praha: Karolinum.

Potměšil, M. (2010) Pocity, postoje a obavy pedagogických pracovníků ve vztahu k inkluzivnímu vzdělávání. In: Havel, J. \& Filová, H., \& kol. Inkluzivní vzdělávání v primární škole. Brno: Paido.

Potměšilová, P. (2014) Supervize v podmínkách speciálního vzdělávání. Olomouc: UP.

Průcha, J. (2002) Moderní pedagogika. Praha: Portál.

Rue, L. W. \& Byars, L. L. (1990) Instructor's Manual: Supervision: Key Link to Productivity. Homewood: Irwin.

The Salamanca Statement and Framework for Action on Special Needs Education. (1994) [online] cit. 27. 7. 2014 dostupné $z$ http://www.unesco.org/education/pdf/SALAMA_E.PDF.

Spilková, V. \& Tomková, A. \& kol. (2010) Kvalita učitele a profesní standard. Výzkumný záměr Učitelská profese v měnících se požadavcích na vzdělávání. Praha: UK.

Stanley, P. D. \& Clinton, J. R. (2011) Křest'anský rádce. Praha: Návrat domů.

Truskovka, Ž. (2010) Interchanges of implementing supervision or professional counselling support im professional eduation of prospective social pedagogus. [online] cit. 27. 4. 2012 dostupné z: http://www.nbuv.gov.ua/PORTAL/Soc_Gum/Staptp/2010_44/files/ST44_35.pdf.

Vágnerová, M. (2000) Patopsychologie pro pomáhající profese. Praha: Portál.

Vančurová, J. (2011) Zdravotně postižení a znevýhodnění žáci v regionálním školství. Školství, č. 13, s. 10.

Vyhláška MŠMT č. 73/2005 Sb., o vzdělávání dětí, žáků a studentů se speciálními vzdělávacími potrebami a dětí, žáků a studentů mimořádně nadaných, ze dne 9. února 2005 ve znění novely č. 147/2011 Sb. ze dne 9. června 2011.

ZÁKON č. 370/2012 Sb., kterým se mění zákon č. 561/2004 Sb., o předškolním, základním, středním, vyšším odborném a jiném vzdělávání, ze dne 9. listopadu 2012.

Odkazy na webové stránky:

http://www.czso.cz/csu/2006edicniplan.nsf/p/3307-06

http://www.inkluze.cz/inkluzivni-vzdelavani/clanek-470/metodika-prace-s-zakem-s-postizenim http://www.uiv.cz

\section{Autor}

PhDr. \& Mgr. Petra Potměšilová, Ph.D., Univerzita Palackého v Olomouci, Cyrilometodějská teologická fakulta, Univerzitní 22, 77111 Olomouc, e-mail: petra.potmesilova@upol.cz

prof. PaedDr., PhDr. Miloň Potměšil, Ph.D., Univerzita Palackého v Olomouci, Pedagogická fakulta, Žižkovo nám. 5, 77140 Olomouc, mvpotmesil@gamil.com

Výzkumné aktivity, které byly zdrojem k vytvoření tohoto článku, byly podpořeny z projektů IGA CMTF_2014_017 a PedF_2013_013. 


\title{
Pedagogues in the conditions of integration education
}

\begin{abstract}
Children and pupils with special educational needs are becoming increasingly integrated into the mainstream educational process. In reality, there may be situations where during their education students with special needs come into contact with pedagogues who do not have the required specific competences. The aim of this paper is not only to describe briefly the conditions for integrated education, but also to summarize the requirements and support the staff needs in order to work more effectively on the basis of the respondents' concerns. Morevoer, the concerns of the pedagogues working in integrated educationwere analyzed by using qualitative tufts. The results of the analysis were related to the teachers' social conditions. The proposed support activities are divided according to the possible forms of preparation and follow-up support. The results and recommendations are based on the practical experience acquired during the praparationof students in Social Pedagogy at St. Cyril and Methodius Theological Faculty of the Palacky University in Olomouc.
\end{abstract}

Key words: pedagogue, social pedagogue, integrated education, child/pupil with special needs 